\title{
Recurrent Blastic Plasmacytoid Dendritic Cell Neoplasm
}

National Cancer Institute

\section{Source}

National Cancer Institute. Recurrent Blastic Plasmacytoid Dendritic Cell Neoplasm. NCI

Thesaurus. Code C156103.

The reemergence of a blastic plasmacytoid dendritic cell neoplasm after a period of remission. 